\title{
Prediction of ground water quality index to assess suitability for drinking purposes using fuzzy rule-based approach
}

\author{
A. K. Gorai $\cdot$ S. A. Hasni $\cdot$ Jawed Iqbal
}

Received: 8 April 2014/ Accepted: 16 October 2014/Published online: 9 November 2014

(c) The Author(s) 2014. This article is published with open access at Springerlink.com

\begin{abstract}
Groundwater is the most important natural resource for drinking water to many people around the world, especially in rural areas where the supply of treated water is not available. Drinking water resources cannot be optimally used and sustained unless the quality of water is properly assessed. To this end, an attempt has been made to develop a suitable methodology for the assessment of drinking water quality on the basis of 11 physico-chemical parameters. The present study aims to select the fuzzy aggregation approach for estimation of the water quality index of a sample to check the suitability for drinking purposes. Based on expert's opinion and author's judgement, 11 water quality (pollutant) variables (Alkalinity, Dissolved Solids (DS), Hardness, $\mathrm{pH}, \mathrm{Ca}, \mathrm{Mg}, \mathrm{Fe}$, Fluoride, As, Sulphate, Nitrates) are selected for the quality assessment. The output results of proposed methodology are compared with the output obtained from widely used deterministic method (weighted arithmetic mean aggregation) for the suitability of the developed methodology.
\end{abstract}

Keywords Water quality index (WQI) · Fuzzy aggregation - Analytical hierarchical process (AHP)

\section{Introduction}

Groundwater is an important and limited resource in many parts of the world and it is extremely important and heavily used in areas where surface water bodies are significantly

A. K. Gorai $(\varangle) \cdot$ S. A. Hasni · J. Iqbal

Department of Civil and Environmental Engineering, Birla Institute of Technology, Mesra, Ranchi 835215, Jharkhand, India

e-mail: amit_gorai@yahoo.co.uk low. Groundwater quality depends on the quality of recharged water, atmospheric precipitation, inland surface water, and on sub-surface geochemical processes. Temporal changes in the origin and constitution of the recharged water, hydrologic and human factors, may cause periodic changes in groundwater quality. Water pollution not only affects water quality but also threats human health, economic development, and social prosperity (Milovanovic 2007).

A water quality index (WQI) is a mechanism for presenting a cumulatively derived numerical expression defining a certain level of water quality. In other words, WQI summarizes large amounts of water quality data into simple terms (e.g., excellent, good, bad, etc.) for reporting to management and the public in a consistent manner. The concept of WQI is based on the comparison of the water quality parameters with respective regulatory standards and gives a single value to the water quality of a source, which translates the list of constituents and their concentrations present in a sample (Khan et al. 2003; Abbasi 2002). The index method was initially proposed by Horton in (1965). Since then, the formulation and use of indices has been strongly advocated by agencies responsible for water supply and control of water pollution. Landwehr (1979) points out that an index is a performance measurement that aggregates information into a usable form, which reflects the composite influence of significant physical, chemical and biological parameters of water quality conditions. House and Newsome (1989) states that the use of a water quality index (WQI) allows 'good' and 'bad' water quality to be quantified by reducing a large quantity of data on a range of physico-chemical and biological parameters to be a single number in a simple, objective and reproducible manner. Various types of aggregation methods used for aggregation of quality-monitoring data to yield an overall 
quality index. Over the last three decades, a number of mathematical functions for aggregation of water quality and water pollution indices have been suggested (Horton 1965; Brown et al. 1970; Prati et al. 1971; Dinius 1972; Dee et al. 1973; McDuffie and Haney 1973; Inhaber 1974; Walski and Parker 1974; Truett et al. 1975; Landwehr and Deininger 1976; Ross 1977; Ott 1978; Stoner 1978; Ball and Church 1980; Bhargava 1983; Dinius 1987; House and Ellis 1987; Smith 1989, 1990; Dojlido et al. 1994; Štambuk-Giljanovic 1999; Pesce and Wunderlin 2000; Swamee and Tyagi 2000; Jonnalagadda and Mhere 2001; Cude 2001; Abbasi 2002; Nagels et al. 2002; Said et al. 2004; Debels et al. 2005; Bordalo et al. 2006; Kannel et al. 2007; Swamee and Tyagi 2007). The different aggregation functions can be of additive, multiplicative, minimum or maximum operator forms. Each functions have their own merits and demerits and applicable for limited situations. The most appropriate aggregation function is the one that is either free from or minimizes the overestimation (ambiguity), underestimation (eclipsing) and rigidity problems.

There is always a certain degree of arbitrariness inherent in the choice of an aggregation function. The objective of this study is to develop a fuzzy aggregation approach as suitable techniques for handling the water quality data and conducting the water pollution cumulative risk assessment associated with multi-pollutant under uncertainty. Fuzzy aggregation is the process by which the fuzzy sets that represent the outputs of each rule are combined into a single fuzzy set. Finally, the input for the defuzzification process is a fuzzy set (aggregated output fuzzy set) and the output is a single number.
There are four basic steps primarily involved in water pollution index design: selection of key water pollutant variables; determination of weight for each selected variables; formulation of sub-indices for each parameter; and aggregation of the sub-indices to yield an overall aggregate index.

The study aims to demonstrate the application of soft computing approach for the prediction of water quality index (WQI).

\section{Development of hierarchical fuzzy model for prediction of water quality index}

The present study aims to develop a hierarchical fuzzy model for the prediction of water quality index. The fuzzy logic formalism has been used to determine water quality index based on fuzzy reasoning. Comparison has been done with the output obtained from deterministic method (Conventional WQI). A number of artificial data set has been prepared for the demonstration of the water quality assessment. In each data set the concentration of each eleven water quality parameters considered for the study are assumed judiciously to cover the various range of the concentration. Membership functions of the determinants and fuzzy rule bases were defined. The model was evaluated with artificial water quality data set based on Mamdani fuzzy inference system.

The methodology for the development of the fuzzy model to predict the water quality index involves the following steps:
Fig. 1 Structure of hierarchical fuzzy expert system for prediction of water quality index $\underline{\text { Input Layer }}$

$\underline{\text { Intermediate Layer }}$

Output Layer

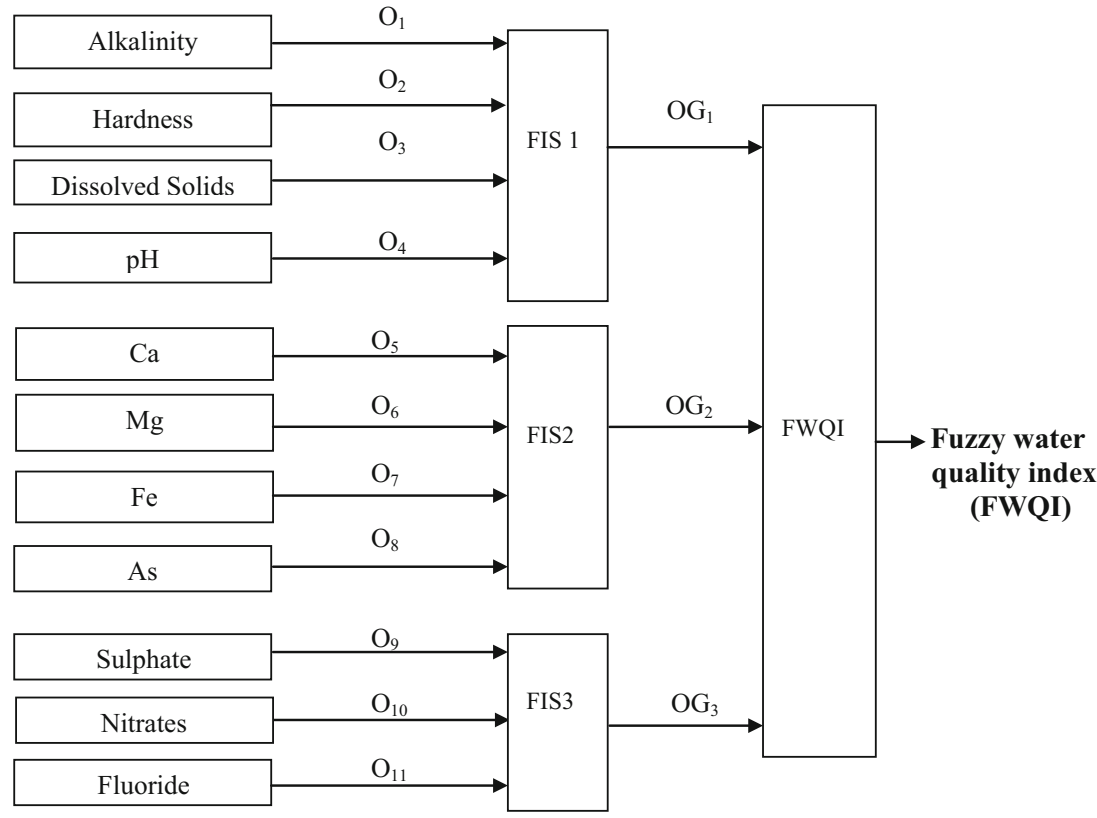


Step I: identification of the system's variables The first and most important step in modelling is the identification of system's input and output variables. The structure of the hierarchical fuzzy model is shown in Fig. 1. The structure of the model reveals that first fuzzy model (FIS1) has four input parameters (Alkalinity, Dissolved Solids, Hardness and $\mathrm{pH}$ ), and second model (FIS2) has also four input parameters ( $\mathrm{Ca}, \mathrm{Mg}, \mathrm{Fe}$, and As) whereas third model (FIS3) has three input parameters (sulphate, nitrate and fluoride). The output values of model FIS1, FIS2 and FIS3 are OG1, OG2, and OG3, respectively then aggregated in the subsequent model to get the final output fuzzy water quality index (FWQI). This relationship between inputs and output can mathematically be expressed as

FIS1 $=f($ Alkalinity, Dissolved Solids, Hardness, $\mathrm{pH})$

FIS2 $=f(\mathrm{Ca}, \mathrm{Mg}, \mathrm{Fe}, \mathrm{As})$

FIS $3=f$ (Sulphate, Nitrates, Fluoride)

$\mathrm{FWQI}=f(\mathrm{FIS} 1, \mathrm{FIS} 2, \mathrm{FIS} 3)$

Step II: determination of the ranges of input and output variables The second step is to determine the ranges of the input and output variables. The minimum value for all the parameters are considered as zero except $\mathrm{pH}$ for reflecting the best water quality. For $\mathrm{pH}$ is equal to 7 representing the best water quality. Similarly, the maximum value is selected for each water quality parameters on the basis of permissible concentrations as per drinking water quality standards (IS 10500). The maximum value for each water quality parameters are four times the permissible concentrations except $\mathrm{pH}$. The drinking water quality standards (IS 10500) for each water quality parameters considered in the study is listed in Table 1. These variables (water quality parameters) in fuzzy modelling are defined as linguistic variables whose linguistic values are words or sentences in a natural or synthetic language. Table 2 shows

Table 1 Drinking water quality standards (Indian standard specification for drinking water: IS 10500, 1983)

\begin{tabular}{lll}
\hline Sl. No. & Parameter & Requirement desirable limit \\
\hline 1 & Alkalinity & $200 \mathrm{mg} / \mathrm{l}$ \\
2 & Total hardness & $300 \mathrm{mg} / \mathrm{l}$ \\
3 & $\mathrm{pH}$ & $6.5-8.5$ \\
4 & $\mathrm{DS}$ & $500 \mathrm{mg} / \mathrm{l}$ \\
5 & $\mathrm{Ca}$ & $75 \mathrm{mg} / \mathrm{l}$ \\
6 & $\mathrm{Mg}$ & $30 \mathrm{mg} / \mathrm{l}$ \\
7 & As & $0.05 \mathrm{mg} / \mathrm{l}$ \\
8 & Fluoride & $1.5 \mathrm{mg} / \mathrm{l}$ (maximum permissible value) \\
9 & Sulphate & $200 \mathrm{mg} / \mathrm{l}$ \\
10 & Nitrate & $45 \mathrm{mg} / \mathrm{l}$ \\
11 & Iron $(\mathrm{Fe})$ & $0.3 \mathrm{mg} / \mathrm{l}$ \\
\hline
\end{tabular}

the linguistic variables, their linguistic values and associated fuzzy intervals.

Step III: selection of the membership functions for various inputs and output variables The next step is to express linguistic values in the form of fuzzy sets, which are

Table 2 Inputs and output with their associated fuzzy values

\begin{tabular}{|c|c|c|c|c|}
\hline $\begin{array}{l}\text { S1. } \\
\text { no. }\end{array}$ & $\begin{array}{l}\text { System's } \\
\text { variables }\end{array}$ & $\begin{array}{l}\text { Linguistic } \\
\text { variables }\end{array}$ & Linguistic values & $\begin{array}{l}\text { Fuzzy } \\
\text { intervals }\end{array}$ \\
\hline \multirow[t]{40}{*}{1} & \multirow[t]{33}{*}{ Input } & \multirow[t]{3}{*}{ Alkalinity } & Good $(G)$ & $0-400$ \\
\hline & & & Moderate (M) & $100-700$ \\
\hline & & & Poor (P) & $400-800$ \\
\hline & & \multirow{3}{*}{$\begin{array}{l}\text { Dissolved } \\
\text { Solids }\end{array}$} & Good (G) & $0-800$ \\
\hline & & & Moderate (M) & $200-1,600$ \\
\hline & & & Poor (P) & $800-2,000$ \\
\hline & & \multirow[t]{3}{*}{ Hardness } & Good (G) & $0-500$ \\
\hline & & & Moderate (M) & $100-900$ \\
\hline & & & Poor (P) & $500-1,200$ \\
\hline & & \multirow[t]{3}{*}{$\mathrm{pH}$} & Good (G) & $5.5-9.5$ \\
\hline & & & Moderate (M) & $0-7$ \\
\hline & & & Poor $(\mathrm{P})$ & $7-14$ \\
\hline & & \multirow[t]{3}{*}{$\mathrm{Ca}$} & Good (G) & $0-150$ \\
\hline & & & Moderate (M) & $50-250$ \\
\hline & & & Poor $(\mathrm{P})$ & $150-300$ \\
\hline & & \multirow[t]{3}{*}{$\mathrm{Mg}$} & Good (G) & $0-60$ \\
\hline & & & Moderate (M) & $20-100$ \\
\hline & & & Poor (P) & $60-120$ \\
\hline & & \multirow[t]{3}{*}{$\mathrm{Fe}$} & Good (G) & $0-0.6$ \\
\hline & & & Moderate (M) & $0.2-1$ \\
\hline & & & Poor $(\mathrm{P})$ & $0.6-1.2$ \\
\hline & & \multirow[t]{3}{*}{ As } & Good (G) & $0-0.09$ \\
\hline & & & Moderate (M) & $0.03-0.18$ \\
\hline & & & Poor $(\mathrm{P})$ & $0.09-0.2$ \\
\hline & & \multirow[t]{3}{*}{ Sulphate } & Good $(\mathrm{G})$ & $0-400$ \\
\hline & & & Moderate (M) & $150-650$ \\
\hline & & & Poor $(\mathrm{P})$ & $400-800$ \\
\hline & & \multirow[t]{3}{*}{ Nitrates } & Good $(\mathrm{G})$ & $0-80$ \\
\hline & & & Moderate (M) & $20-140$ \\
\hline & & & Poor $(\mathrm{P})$ & 80-180 \\
\hline & & \multirow[t]{3}{*}{ Fluoride } & Good (G) & $0-3$ \\
\hline & & & Moderate (M) & $1-5$ \\
\hline & & & Poor $(\mathrm{P})$ & $3-6$ \\
\hline & \multirow[t]{7}{*}{ Output } & \multirow[t]{7}{*}{ FWQI } & $\begin{array}{l}\text { Very very low } \\
\text { (VVL) }\end{array}$ & $0-0.667$ \\
\hline & & & Very low (VL) & $0-1.334$ \\
\hline & & & Low (L) & $0.667-2$ \\
\hline & & & Medium (M) & $1.334-2.667$ \\
\hline & & & High $(\mathrm{H})$ & $2-3.333$ \\
\hline & & & Very high (VH) & $2.667-4$ \\
\hline & & & $\begin{array}{l}\text { Very very high } \\
\text { (VVH) }\end{array}$ & $3.333-4$ \\
\hline
\end{tabular}


represented by its membership functions. The amount of overlap and the shape of fuzzy sets should be considered by an expert for each input variable. The triangular membership function is the simplest one and has been used due to its computational efficiency. The membership functions for all inputs and output are shown in Fig. 2a-l.

Step IV: Formation of the set of linguistic rules The next step is to writing the linguistic rules. The rule base is a set of linguistic statements in the form of IF-THEN rules with antecedents and consequents, respectively, connected by AND operator. In general, a fuzzy rule-based system with multi-inputs single-output (MISO) can be represented in the following manner:
$R^{(\mathrm{i})}:$ IF $X_{1}$ is $B_{1}^{(\mathrm{i})}$ AND $X_{2}$ is $B_{2}^{(\mathrm{i})} \mathrm{AND} \ldots$. AND $X_{\mathrm{n}}$ is $B_{\mathrm{n}}^{(\mathrm{i})}$ THEN $Y_{1}$ is $D_{1}^{(\mathrm{i})}$

where $X_{1}, X_{2} \ldots, X_{\mathrm{n}}$ are the input linguistic variables and $Y_{1}$ is the output linguistic variables, $B_{1}^{(\mathrm{i})}, B_{2}^{(\mathrm{i})}, \ldots B_{\mathrm{n}}^{(\mathrm{i})}$ and $D_{1}^{(\mathrm{i})}$ are linguistic values defined by fuzzy sets on $X_{1}, X_{2} \ldots X_{\mathrm{n}}$ and $Y_{1}$, respectively.

Rule bases for each FIS are written separately and represented in Tables 3, 4, 5 and 6 for FIS1, FSI2, FIS3 and FWQI, respectively. Table 3 and 4 represents 81 number of rule bases for FIS1 and FIS, respectively. Similarly, Table 5 and 6 represents 27 number of rule bases for FIS 3 and FWQI, respectively.
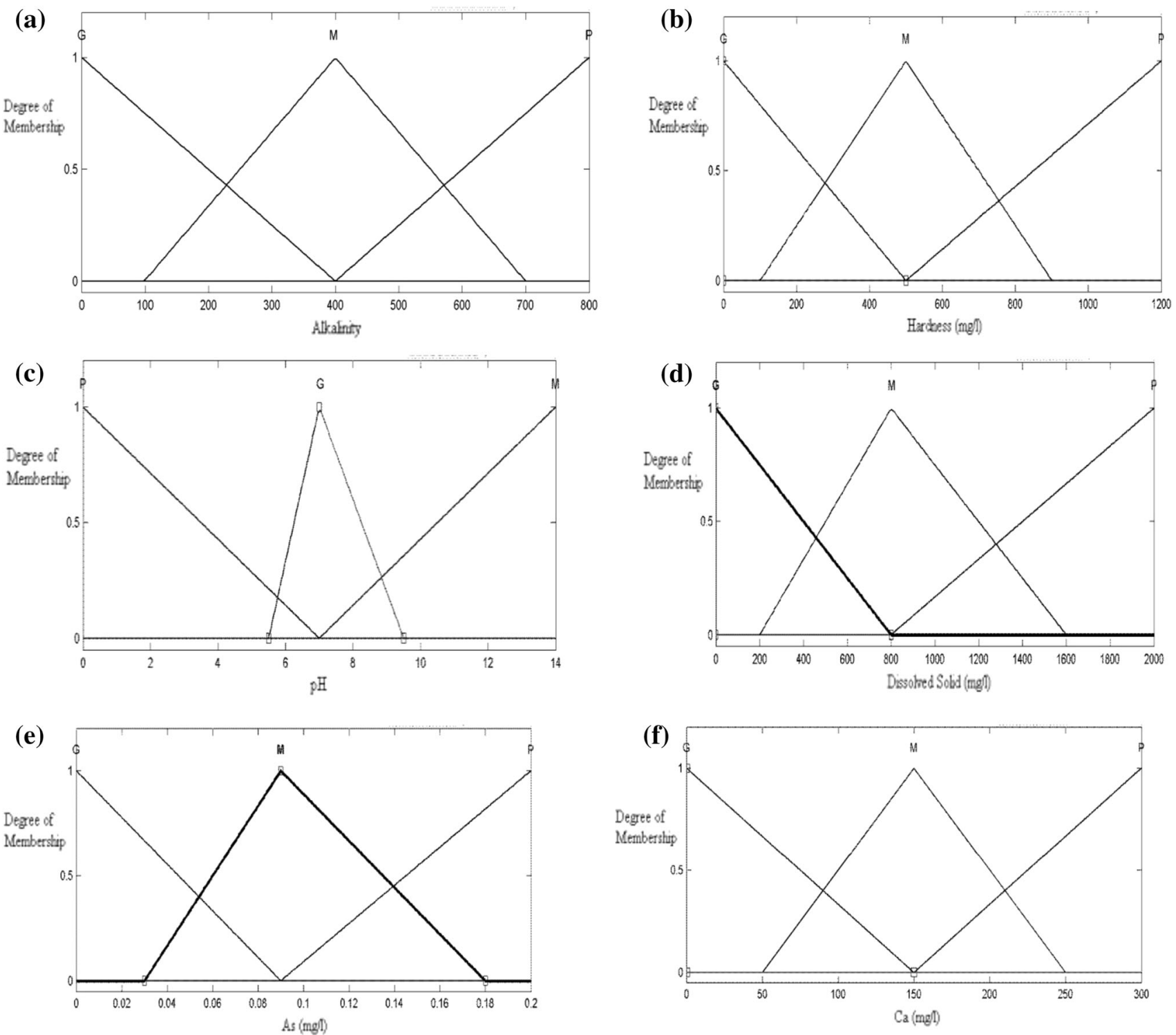

Fig. 2 Membership function of input and output variables a alkalinity $\mathbf{b}$ hardness $\mathbf{c} \mathrm{pH} \mathbf{d}$ dissolved solids (DS) e As $\mathbf{f}(\mathrm{Ca}) \mathbf{g}$ Fe $\mathbf{h} \mathrm{Mg} \mathbf{i} \mathrm{Nitrate}$ j Sulphate k Fluoride I FWQI 

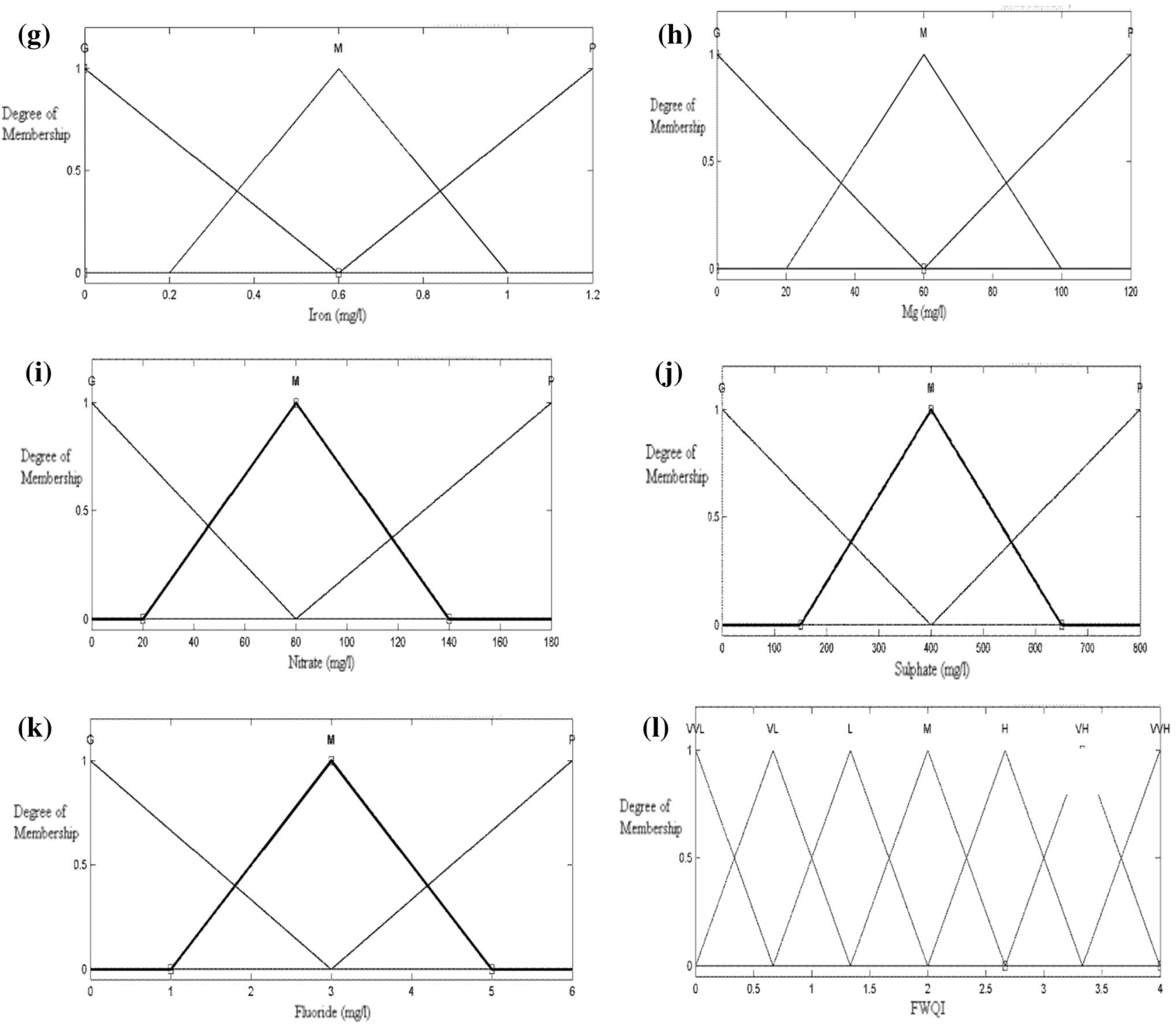

Fig. 2 continued

Table 3 Rule base for FIS 1

\begin{tabular}{llllll}
\hline Rule & Alkalinity & $\mathrm{pH}$ & Dissolved Solids & Hardness & FIS1 \\
\hline 1 & Low & Low & Low & Low & EL \\
2 & Low & Low & Low & Moderate & VVL \\
3 & Low & Low & Moderate & Low & VL \\
$\ldots \ldots \ldots \ldots \ldots \ldots \ldots \ldots$ & & & \\
$\ldots \ldots \ldots \ldots \ldots \ldots \ldots \ldots \ldots$ & & & \\
$\ldots \ldots \ldots \ldots \ldots \ldots \ldots \ldots$ & & & \\
80 & Moderate & High & High & High & VVH \\
81 & High & High & High & High & EH \\
\hline
\end{tabular}

Table 4 Rule base for FIS 2

\begin{tabular}{llllll}
\hline Rule & Ca & $\mathrm{Mg}$ & $\mathrm{Fe}$ & As & FIS2 \\
\hline 1 & Low & Low & Low & Low & EL \\
2 & Low & Low & Low & Moderate & VVL \\
3 & Low & Low & Moderate & Low & VL \\
$\ldots \ldots \ldots \ldots \ldots \ldots \ldots \ldots$ & & & & \\
$\ldots \ldots \ldots \ldots \ldots \ldots \ldots \ldots$ & & & & \\
80 & Moderate & High & High & High & VVH \\
81 & High & High & High & High & EH \\
\hline
\end{tabular}

The present methodology to develop fuzzy model for prediction of water quality index (WQI) has been implemented on Fuzzy Logic Toolbox of MATLAB7.

Step V: fuzzy inference and defuzzification The final step is to select the fuzzy inference system for the suitable aggregation and defuzzification of the output to obtain the crisp output. Fuzzification is the process of transforming 
the real value inputs into fuzzy values whereas the defuzzification process is the way of transforming fuzzy outputs into real values. The output of the model is calculated using the centroid method. Centroid method is characterized for calculating the gravity center of the final membership function as follows:

Table 5 Rule base for FIS 3

\begin{tabular}{lllll}
\hline Rule & Sulphate & Nitrate & Fluoride & FIS3 \\
\hline 1 & Low & Low & Low & VVL \\
2 & Low & Low & Low & VL \\
3 & Low & Low & Moderate & L \\
$\ldots \ldots \ldots \ldots \ldots \ldots \ldots \ldots$ & & & \\
$\ldots \ldots \ldots \ldots \ldots \ldots \ldots \ldots$ & & & \\
$\ldots \ldots \ldots \ldots \ldots \ldots \ldots \ldots$ & & High & VH \\
26 & Moderate & High & High & VVH \\
27 & High & High & &
\end{tabular}

Table 6 Rule base for FWQI

\begin{tabular}{lllll}
\hline Rule & FIS1 & FIS2 & FIS3 & FWQI \\
\hline 1 & Low & Low & Low & VVL \\
2 & Low & Low & Low & VL \\
3 & Low & Low & Moderate & L \\
$\ldots \ldots \ldots \ldots \ldots \ldots \ldots \ldots$ & & & \\
$\ldots \ldots \ldots \ldots \ldots \ldots \ldots \ldots \ldots$ & & & \\
$\ldots \ldots \ldots \ldots \ldots \ldots \ldots \ldots$ & & & \\
26 & Moderate & High & High & VH \\
27 & High & High & High & VVH \\
\hline
\end{tabular}

Fuzzy $W Q I=\frac{\int x \mu_{\text {out }}(x) \mathrm{d} x}{\int \mu_{\text {out }}(x) \mathrm{d} x}$

\section{Results and discussion}

The rules representation of the four models FIS1, FIS2, FIS3 and FWQI are shown in Figs. 3, 5, 7 and 9, respectively. The surface views of the FIS1, FIS2, FIS3 and FWQI models are shown in Figs. $4 \mathrm{a}-\mathrm{f}, 6 \mathrm{a}-\mathrm{f}, 8 \mathrm{a}-\mathrm{c}$ and $10 \mathrm{a}-\mathrm{c}$, respectively.

The rule base representation in Fig. 3 indicate that the probable value of FIS1 is 1.73 for the respective average concentrations/value of Alkalinity, Dissolved Solids, Hardness, and $\mathrm{pH}$ are 400, 1,000, $600 \mathrm{mg} / \mathrm{l}$ and 7. The results are summarised in 3D plots as shown in Fig. 4a-f. Figure 4a shows FIS1 values as a function of Alkalinity and Dissolved Solids as the input while the third (Hardness) and fourth input $(\mathrm{pH})$ are hidden in the view. The model clearly indicates that as either the Alkalinity or Dissolved Solids increases, the FIS1 also increases. Similarly, the model for FIS1 with other combinations of inputs and associated default variables can be explained.

Similarly, the rule base representation in Fig. 5 indicate that probable value of FIS2 is 2.03 for the average concentrations of $\mathrm{Ca}, \mathrm{Mg}, \mathrm{Fe}$ and $\mathrm{As}$ are 150, 60, 0.6 and $0.1 \mathrm{mg} / \mathrm{l}$, respectively. The results are summarised in 3D plots in Fig. 6a-f. Figure 6a shows FIS2 as a function of $\mathrm{Ca}$ and $\mathrm{Mg}$ as the input while the third (Fe) and fourth input (As) are hidden in the view. The model clearly indicates that as either the $\mathrm{Ca}$ or $\mathrm{Mg}$ increases, the FIS2 also increases. Similarly, the model for FIS2 with other combinations of inputs and associated default variables can be explained.
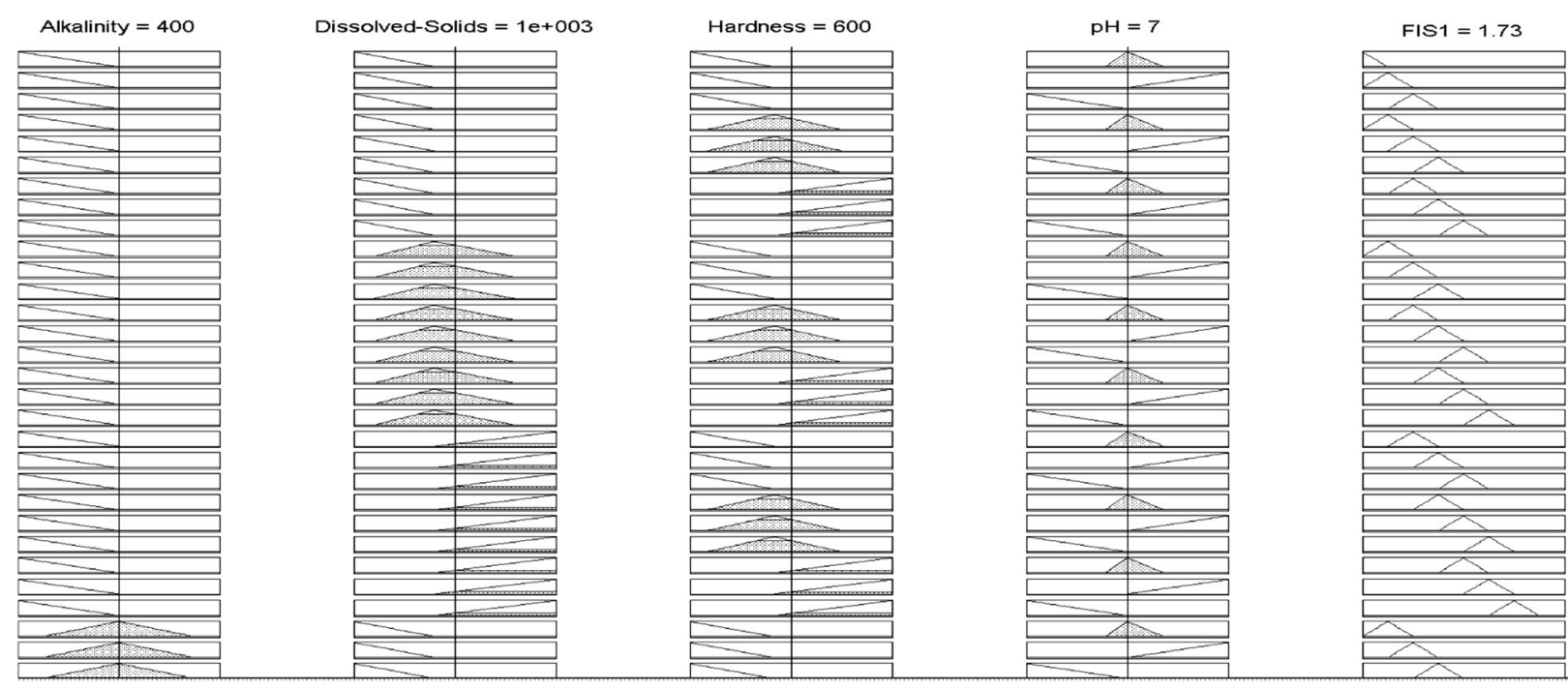

Fig. 3 Representation of rule base of FIS1 Model 

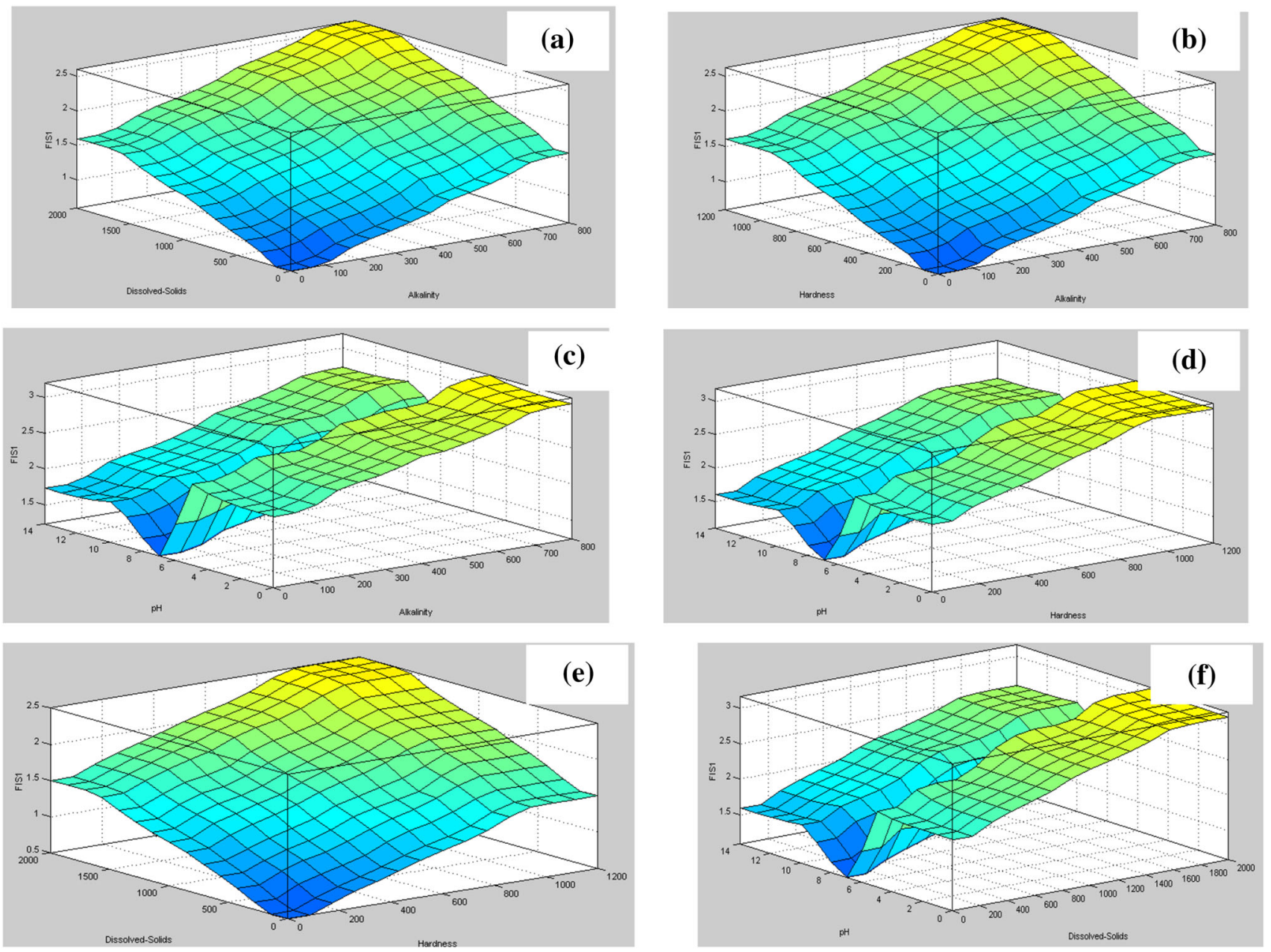

Fig. 4 Surface views of FIS1 model a FIS1 vs. dissolved solids and alkalinity b FIS1 vs. hardness and alkalinity c FIS1 vs. pH and alkalinity d FIS1 vs. pH and hardness e FIS1 vs. dissolved solids and hardness f FIS1 vs. pH dissolved solids
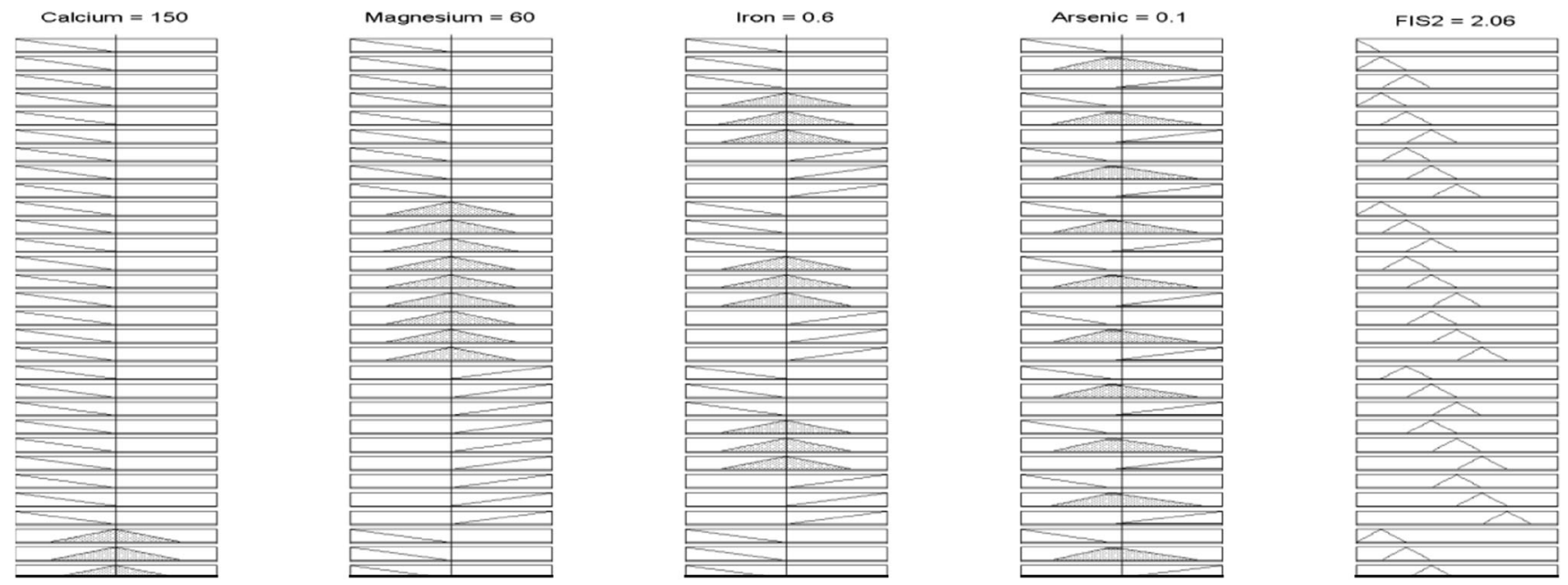

Fig. 5 Representation of rule base of FIS2 Model 

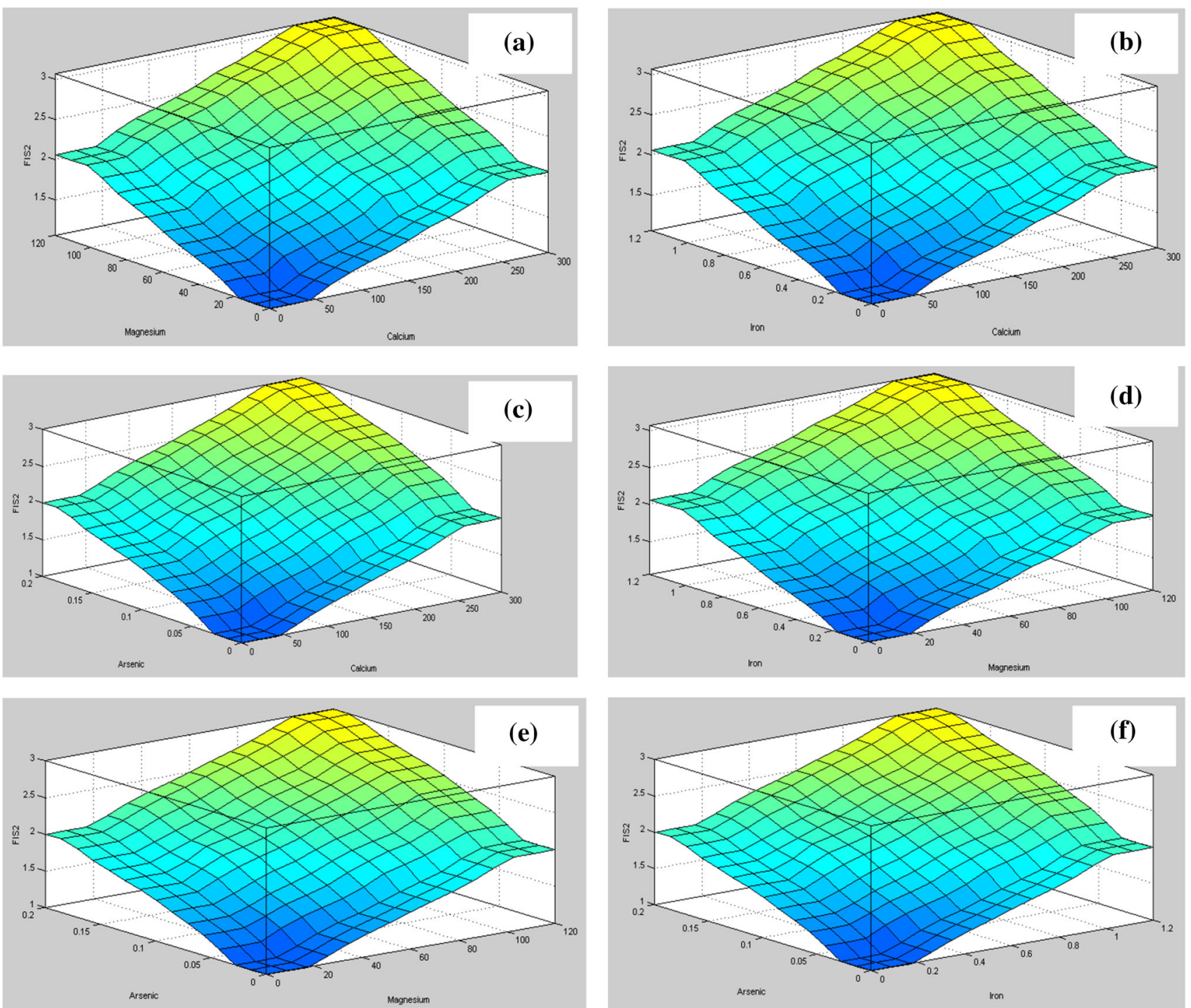

Fig. 6 Surface views of FIS2 model a FIS2 vs. Mg and Ca b FIS2 vs. Fe and Mg c FIS2 vs. As and Mg d FIS2 vs. As and Fe

The rule base representation in Fig. 7 indicate that probable value of FIS3 is 2.09 for the average concentrations of sulphate, nitrate and fluoride are 400, 90 and $3 \mathrm{mg} /$ 1 , respectively. The results are summarised in 3D plots shown in Fig. 8a-c. Figure 8a shows FIS3 as a function of sulphate and nitrate as the input while the third (Fluoride) is hidden in the view. The model clearly indicates that as either the sulphate or nitrate increases, the FIS3 also increases. Similarly, the model for FIS3 with other combinations of inputs and associated default variables can be explained.

Fuzzy water quality index (FWQI) model has been computed as a function of FIS1, FIS2 and FIS3. The rule base representation in Fig. 9 indicates that the probable value of FWQI is 2 for the value of FIS1, FIS2 and FIS3 are 2, 2 and 2, respectively. The results are summarised in
3D plots as shown in Fig. 10a-c. Figure 10a shows fuzzy water quality index (FWQI) as a function of FIS1, and FIS2 as the inputs while the third (FIS3) is hidden in the view. The model clearly indicates that as either the FIS1 or FIS2 increases, the FWQI also increases. Thus, the scale of water quality index is a reducing scale, that is, higher value of WQI indicates poor water quality in the area and vice versa.

\section{Validation of the model}

The validation of the model has been done by comparing the predicted values of fuzzy WQI from the model with that of the deterministic values of WQI. The detailed methodology of deterministic WQI determination is 

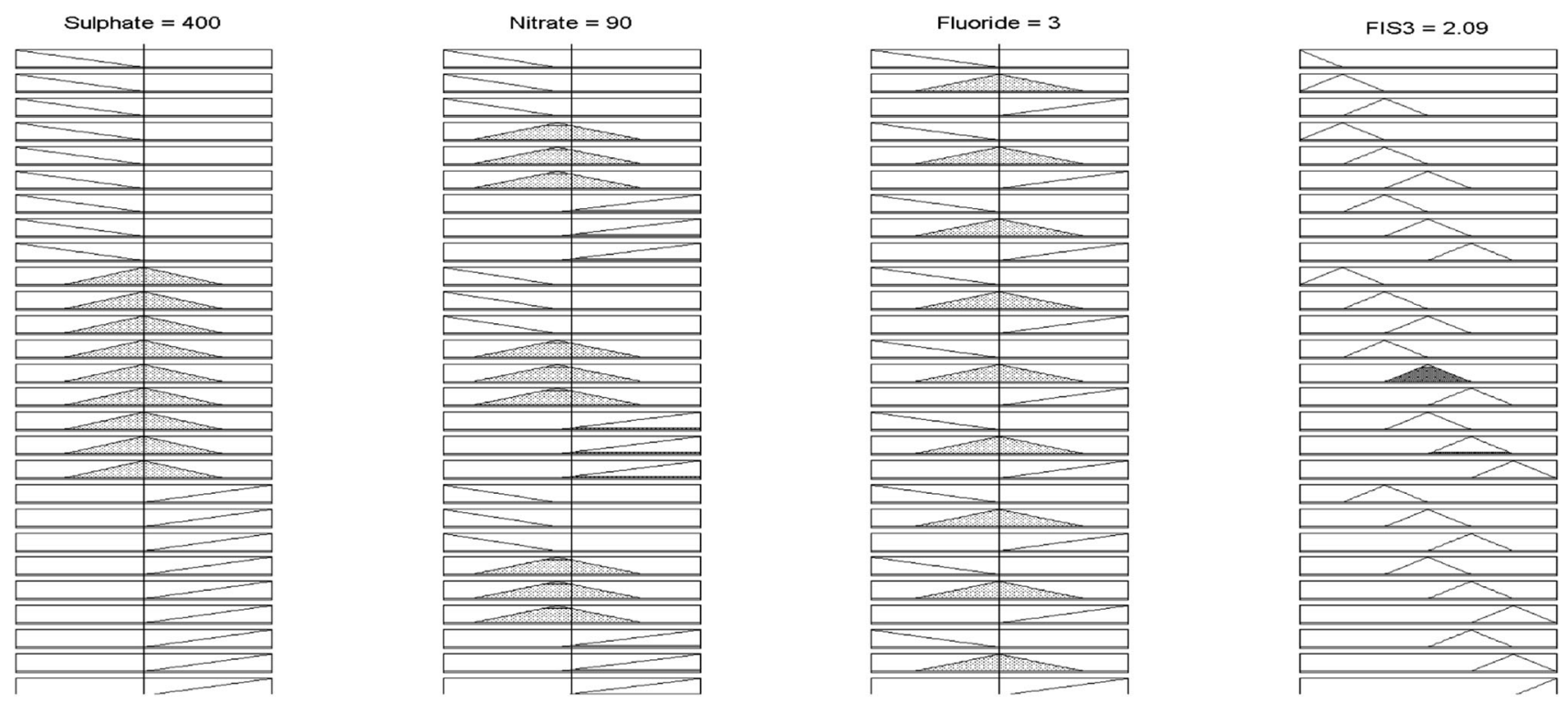

Fig. 7 Representation of rule base of FIS2 Model
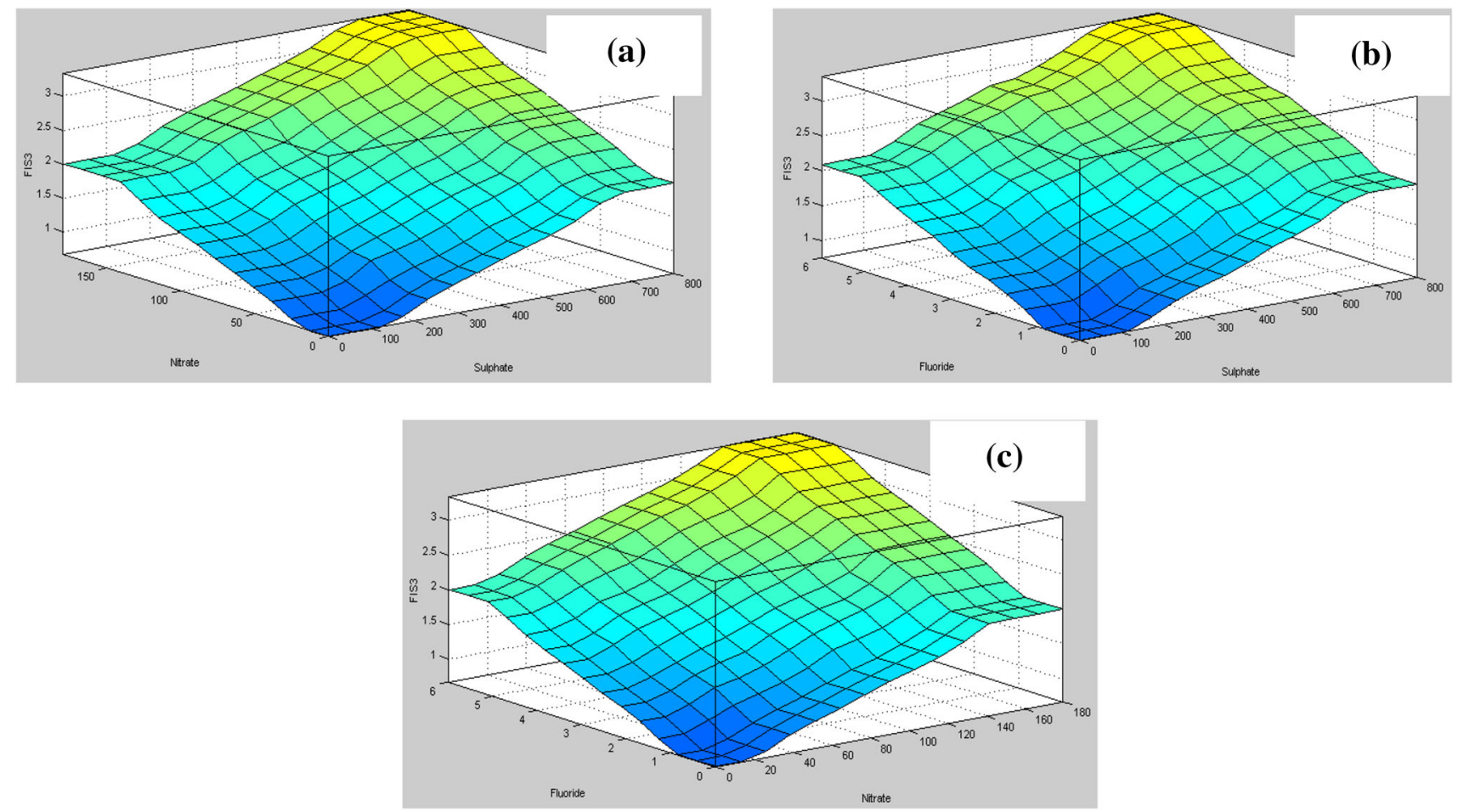

Fig. 8 Surface views of FIS3 model a FIS3 vs. Nitrate and Sulphate b FIS3 vs. Fluoride and Sulphate c FIS3 vs. Fluoride and Nitrate

explained below in the next section. A number of artificial data set (nine) for each water quality parameter has been prepared for comparison of water quality indices. The water quality parameter concentrations in the artificial data set are assumed in such a way that it covers all the possible ranges of pollution concentrations. The artificial dataset thus generated are shown in Table 7. The prediction values of FWQ indices for all the dataset are listed in Table 7. The predicted values WQI are compared with the deterministic WQI. The deterministic 


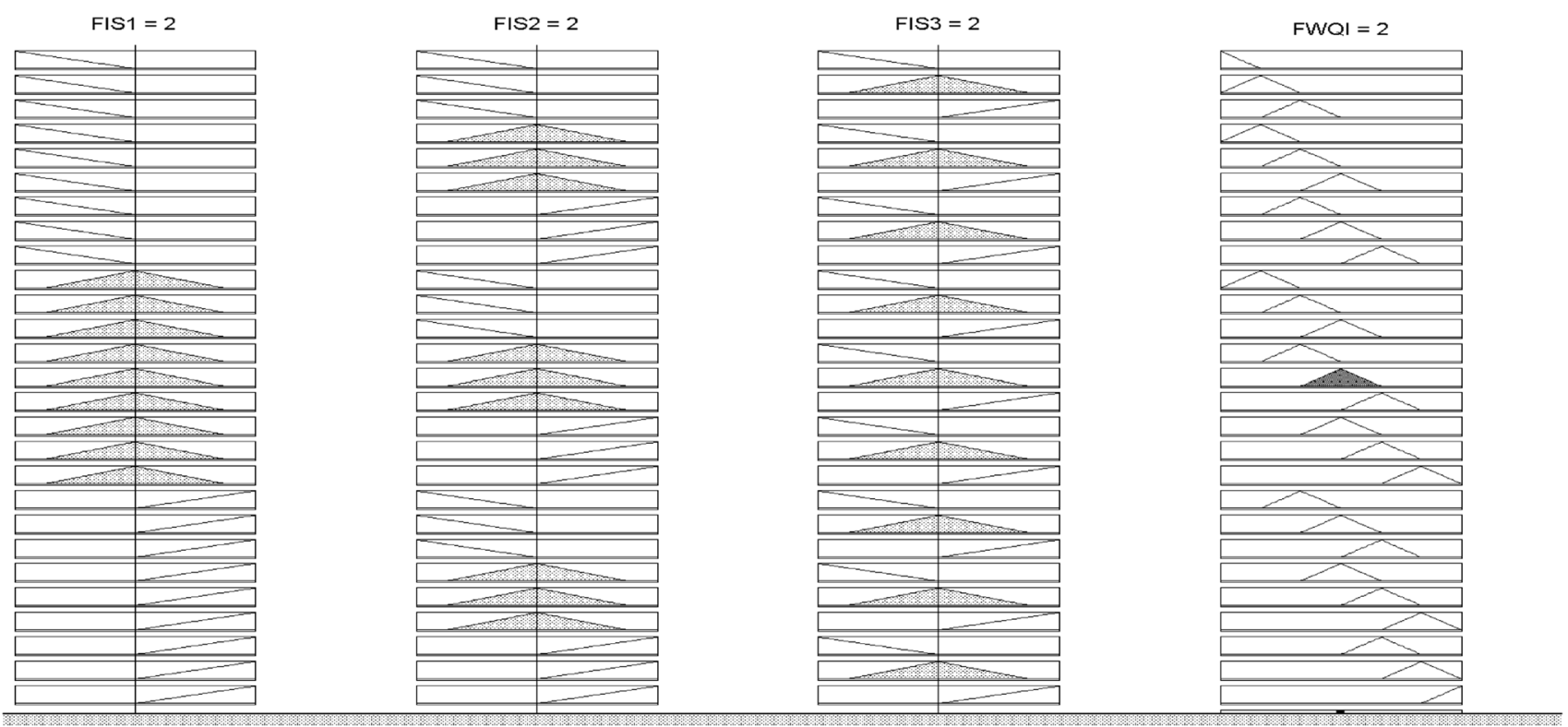

Fig. 9 Representation of rule base of FWQI Model
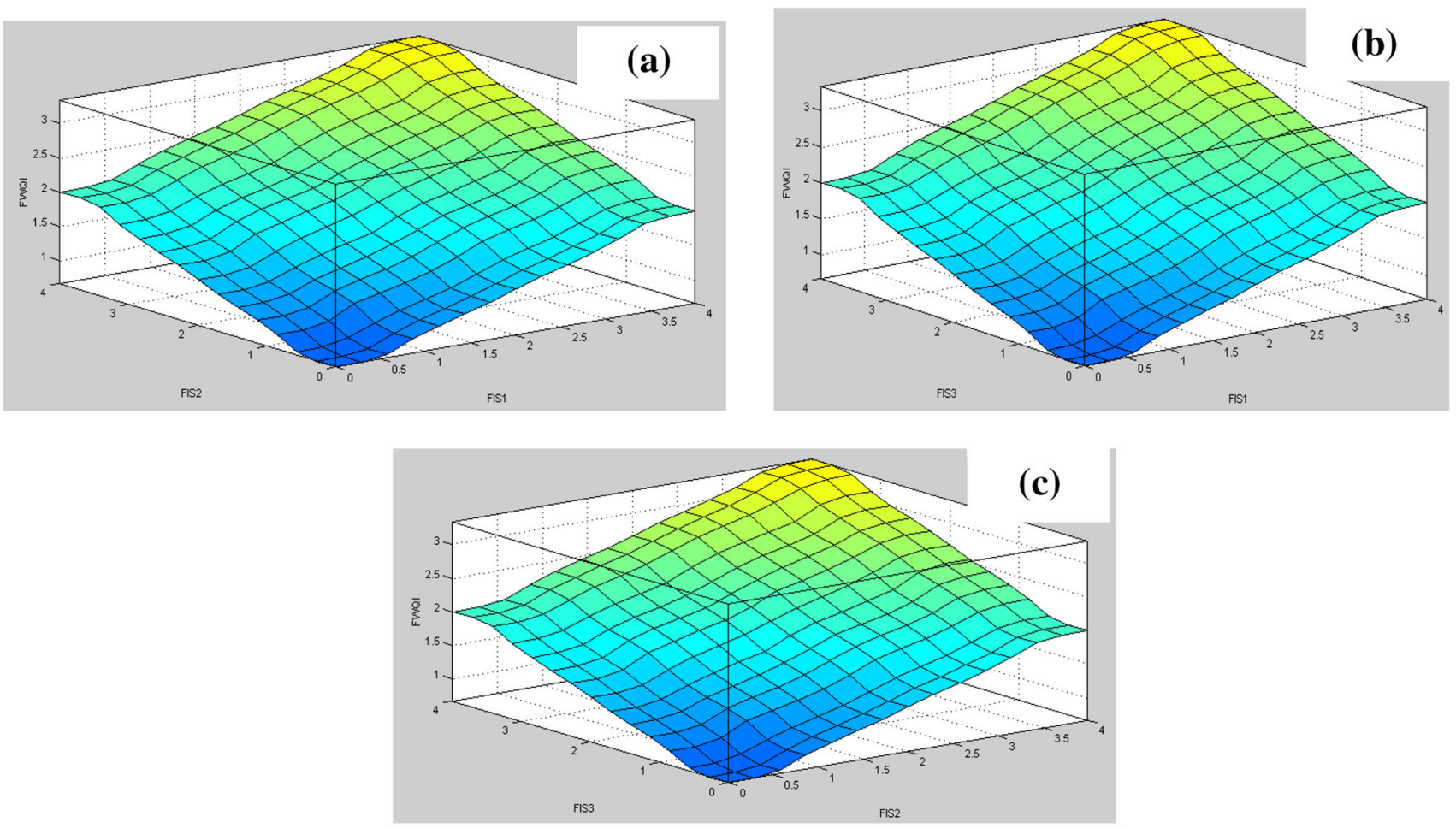

Fig. 10 Surface views of FWQI model a FWQI vs. FIS1 and FIS2 b FWQI vs. FIS3 and FIS1 c FWQI vs. FIS3 and FIS2

WQI has been also determined for the same dataset and reported in Table 7 . The predicted values of fuzzy water quality index and deterministic water quality index are plotted as shown in Fig. 11 for the graphical representation of the comparative values. The trend of the FWQI and WQI lines reveals that the developed fuzzy model can be used for the prediction of water quality index and the fuzzy aggregation mechanism for the prediction of water quality index is better representation than that of the existing aggregation method. 
Table 7 Comparative values of Deterministic WQI and Fuzzy WQI for Artificial Dataset

\begin{tabular}{|c|c|c|c|c|c|c|c|c|c|c|c|c|c|}
\hline Condition & Alkalinity & DS & Hardness & $\mathrm{pH}$ & $\mathrm{Ca}$ & $\mathrm{Mg}$ & $\mathrm{Fe}$ & As & Sulphate & Nitrate & Fluoride & Deterministic WQI & FWQI \\
\hline $\mathrm{A}$ & 0.0 & 0.0 & 0.0 & 7.0 & 0.0 & 0.0 & 0.00 & 0.0 & 0.0 & 0.0 & 0.0 & 0.01 & 0.21 \\
\hline $\mathrm{B}$ & 40.0 & 100.0 & 60.0 & 7.4 & 15.0 & 6.0 & 0.06 & 0.01 & 40.0 & 9.0 & 0.3 & 0.25 & 0.21 \\
\hline $\mathrm{C}$ & 80.0 & 200.0 & 120.0 & 7.8 & 30.0 & 12.0 & 0.12 & 0.02 & 80.0 & 18.0 & 0.6 & 0.34 & 0.22 \\
\hline $\mathrm{D}$ & 120.0 & 300.0 & 180.0 & 8.2 & 45.0 & 18.0 & 0.18 & 0.03 & 120.0 & 27.0 & 0.9 & 0.52 & 0.48 \\
\hline $\mathrm{E}$ & 160.0 & 400.0 & 240.0 & 8.4 & 60.0 & 24.0 & 0.24 & 0.04 & 160.0 & 36.0 & 1.2 & 0.71 & 0.99 \\
\hline $\mathrm{F}$ & 200.0 & 500.0 & 300.0 & 8.5 & 75.0 & 30.0 & 0.30 & 0.05 & 200.0 & 45.0 & 1.5 & 1.0 & 1.22 \\
\hline $\mathrm{G}$ & 800.0 & $2,000.0$ & $1,200.0$ & 14.0 & 300.0 & 120.0 & 1.20 & 0.2 & 800.0 & 180.0 & 6.0 & 4.0 & 3.78 \\
\hline $\mathrm{H}$ & 300.0 & 600.0 & 400.0 & 9.5 & 125.0 & 60.0 & 0.60 & 0.1 & 300.0 & 54.0 & 1.8 & 1.4 & 1.46 \\
\hline I & 400.0 & 700.0 & 500.0 & 10.5 & 175.0 & 90.0 & 0.90 & 0.15 & 400.0 & 63.0 & 2.1 & 2.1 & 2.07 \\
\hline
\end{tabular}

Condition A: desirable or minimum value for all the parameters reflecting best water quality, B: $20 \%$ of the permissible limit for all the parameters, C: $40 \%$ of the permissible limit for all the parameters, D: $60 \%$ of the permissible limit for all the parameters, E: $80 \%$ of the permissible limit for all the parameters, F: permissible limit reflecting threshold level of water quality for all the parameters, G: maximum limit for the model application (4 times of the permissible limit), $\mathrm{H}$ and I: arbitrarily assumed the concentration level more than the permissible limit

Fig. 11 Graphical representation of FWQI and deterministic WQI

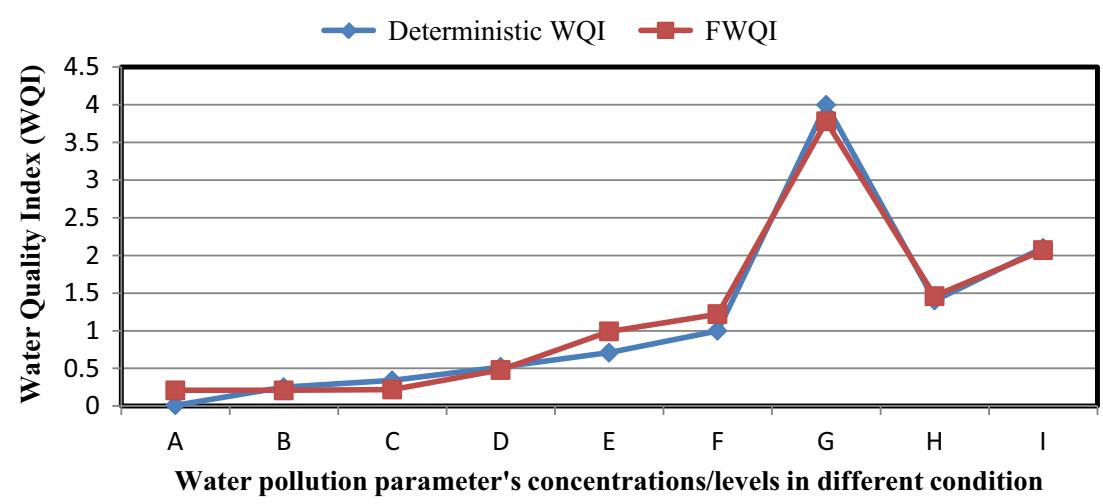

$I_{i}=\frac{C_{i}-C_{\min }}{C_{\mathrm{s}}-C_{\min }}$

where, $C_{i}$ the observed concentration of the $i$ th water quality parameter, $C_{\mathrm{s}}$ the concentration limit value of the $i$ th water quality parameter as mentioned in Table $1 . C_{\min }$ the minimum concentration of the parameter reflecting best water quality, The minimum value for all the parameters considered in the model are 0 except $\mathrm{pH}$ (for $\mathrm{pH}=7$, represent best water quality)

The weightage of individual pollutants can be found out using analytical hierarchy process (AHP). AHP is a systematic method for comparing a list of objectives or alternatives. This method forms a pair-wise comparison matrix ' $A$ ' as shown below, where the number in the $i$ th row and $j$ th column gives the relative importance of individual water pollutant parameter $P_{i}$ as compared with $P_{j}$

The comparison matrix generated by expert ranking using Saaty's scale (1980) is as below: parameter can be determined by 


\begin{tabular}{|c|c|c|c|c|c|c|c|c|c|c|c|}
\hline & $\Gamma \mathrm{pH}$ & Alkalinity & Hardness & DS & $\mathrm{Fe}$ & As & Fluoride & Sulphate & Nitrate & $\mathrm{Ca}$ & $\mathrm{Mg}$ \\
\hline $\mathrm{pH}$ & 1 & 1.25 & 1.25 & 1.25 & 0.667 & 0.334 & 0.5 & 0.667 & 0.667 & 1.11 & 1.11 \\
\hline Alkalinity & 0.8 & 1 & 1 & 1 & 0.667 & 0.334 & 0.5 & 0.667 & 0.667 & 1.25 & 1.25 \\
\hline Hardness & 0.8 & 1 & 1 & 1 & 0.667 & 0.334 & 0.5 & 0.667 & 0.667 & 1.25 & 1.25 \\
\hline DS & 0.8 & 1 & 1 & 1 & 0.667 & 0.334 & 0.5 & 0.667 & 0.667 & 1.25 & 1.25 \\
\hline $\mathrm{Fe}$ & 1.5 & 1.5 & 1.5 & 1.5 & 1 & 0.5 & 0.667 & 1.25 & 1.25 & 2 & 2 \\
\hline As & 3 & 3 & 3 & 3 & 2 & 1 & 1 & 2 & 2 & 5 & 5 \\
\hline Fluoride & 2 & 2 & 2 & 2 & 1.5 & 1 & 1 & 2 & 2 & 5 & 5 \\
\hline Sulphate & 1.5 & 1.5 & 1.5 & 1.5 & 0.8 & 0.5 & 0.5 & 1 & 1 & 1.25 & 1.25 \\
\hline Nitrate & 1.5 & 1.5 & 1.5 & 1.5 & 0.8 & 0.5 & 0.5 & 1 & 1 & 1.25 & 1.25 \\
\hline $\mathrm{Ca}$ & 0.9 & 0.8 & 0.8 & 0.8 & 0.5 & 0.2 & 0.2 & 0.8 & 0.8 & 1 & 1 \\
\hline $\mathrm{Mg}$ & 0.9 & 0.8 & 0.8 & 0.8 & 0.5 & 0.2 & 0.2 & 0.8 & 0.8 & 1 & 1 \\
\hline
\end{tabular}

Taking the sum of each column and then divide each column by the corresponding sum to obtain the normalized matrix. The normalized matrix thus obtained is represented in matrix $\mathrm{N}$ as given below. $\sum_{i=1}^{11} W_{i}=1$

$\left.\begin{array}{cccccc}\hline & & & & & \\ \text { As } & \text { Fluoride } & \text { Sulphate } & \text { Nitrate } & \mathrm{Ca} & \mathrm{Mg} \\ 0.06 & 0.08 & 0.06 & 0.06 & 0.05 & 0.05 \\ 0.06 & 0.08 & 0.06 & 0.06 & 0.06 & 0.06 \\ 0.06 & 0.08 & 0.06 & 0.06 & 0.06 & 0.06 \\ 0.06 & 0.08 & 0.06 & 0.06 & 0.06 & 0.06 \\ 0.10 & 0.11 & 0.11 & 0.11 & 0.09 & 0.09 \\ 0.19 & 0.17 & 0.17 & 0.17 & 0.23 & 0.23 \\ 0.19 & 0.17 & 0.17 & 0.17 & 0.23 & 0.23 \\ 0.10 & 0.08 & 0.09 & 0.09 & 0.06 & 0.06 \\ 0.10 & 0.08 & 0.09 & 0.09 & 0.06 & 0.06 \\ 0.04 & 0.03 & 0.07 & 0.07 & 0.05 & 0.05 \\ 0.04 & 0.03 & 0.07 & 0.07 & 0.05 & 0.05\end{array}\right]$

The relative weight vector $W$ for the pollutants is given by the average of the row elements in matrix $N$ as

$$
W=\left[\begin{array}{c}
w_{\mathrm{pH}} \\
w_{\text {Alkalinity }} \\
w_{\text {Hardness }} \\
w_{\mathrm{DS}} \\
w_{\mathrm{Fe}} \\
w_{\text {As }} \\
w_{\text {Fluoride }} \\
w_{\text {Sulphate }} \\
w_{\text {Nitrate }} \\
w_{\mathrm{Ca}} \\
w_{\mathrm{Mg}}
\end{array}\right]=\left[\begin{array}{c}
0.07 \\
0.06 \\
0.06 \\
0.06 \\
0.10 \\
0.20 \\
0.17 \\
0.09 \\
0.09 \\
0.05 \\
0.05
\end{array}\right]
$$

Thus, the sum of the weightage of the pollutants obtained as
The consistency ratio (CR) of the matrix ' $A$ ' calculated was found to be 0.009 which is $<0.1$ as par Satty (1980) and thus the consistency of matrix $A$ is acceptable.

\section{Conclusions}

The study suggests a robust decision-making tool for drinking water quality management in the form of the fuzzy water quality index (FWQI). The developed methodology demonstrates to determine a single index value to make assessment of drinking water quality more understandable especially in public consideration. This new index is believed to assist decision makers in reporting the state of ground water quality for drinking purposes. It has been demonstrated that computing with linguistic terms within fuzzy inference system 
(FIS) improves the tolerance for imprecise data. The model is developed for water quality assessment with artificial dataset considered eleven water quality (Alkalinity, Hardness, pH, Dissolved Solids, Ca, Mg, As, Fluoride, Sulphate, Nitrate and Iron) parameters. The authors believe that the fuzzy logic concepts, if used logically, could be an effective tool for drinking water policy issues. The fuzzy model developed is applicable only for specific number of water quality parameters in specified range selected.

Acknowledgments The authors thanks to the Vice Chancellor of the Birla Institute of Technology, Mesra for providing the required facility to carry out the work successfully.

Open Access This article is distributed under the terms of the Creative Commons Attribution License which permits any use, distribution, and reproduction in any medium, provided the original author(s) and the source are credited.

\section{References}

Abbasi SA (2002) Water quality indices, state of the art report, National Institute of Hydrology, Scientific contribution no. INCOH/SAR-25/2002, INCOH, Roorkee, p 73

Ball RO, Church RL (1980) Water quality indexing and scoring. J Environ Eng-ASCE 106(4):757-771

Bardalo AA, Nilsumranchit W, Chalermwat K (2001) Water quality and uses of the Bangpakong river (Eastern Thailand). Water Res 35(15):3635-3642

Bhargava DS (1983) Use of a water quality index for river classification and zoning of Ganga river. Environ Pollut B 6:51-67

Bordalo AA, Teixeira R, Wiebe WJ (2006) A water quality index applied to an international shared river basin: the case of the Douro River. Environ Manage 38:910-920

Brown RM, McClelland NI, Deininger RA, Tozer RG (1970) A water quality index — do we dare? Water Sew Works 117(10):339-343

Cude CG (2001) Oregon water quality index: a tool for evaluating water quality management effectiveness. J Am Water Resour Assoc 37(1):125-137

Debels P, Figueroa R, Urrutia R, Barra R, Niell X (2005) Evaluation of water quality in the Chillan river (Central Chile) using physicochemical parameters and a modified water quality index. Environ Monit Assess 110(1-3):301-322

Dee N, Baker J, Drobny N, Duke KM, Whitman I, Fahringer D (1973) An environmental evaluation system for water resource planning. Water Resour Res 9(3):523-535

Dinius SH (1972) Social accounting system for evaluating water resources. Water Resour Res 8(5):1159-1177

Dinius SH (1987) Design of an index of water quality. Water Resour Bull 23(5):833-843

Dojlido J, Raniszewski J, Woyciechowska J (1994) Water quality index-applied to rivers in the Vistula river basin in Poland. Environ Monit Assess 33(1):33-42

Egborge ABM, Coker JB (1986) Water quality index: application in the Warri River, Nigeria. Environ Poll B 12(1):27-40

Giljanovic NS (1999) Water quality evaluation by index in Dalmatia. Water Res 33(16):3423-3440

Horton RK (1965) An index number system for rating water quality. J Water Poll Control Fed 37(3):300-306

House MA, Ellis JB (1987) The development of water quality indices for operational management. Water Sci Technol 19(9):145-154
House MA, Newsome DH (1989) Water quality indices for the management of surface water quality. Water Sci Technol 21:1137-1148

Indian Standard Specification for Drinking Water (1983) IS-105001983, Indian Standards Institution, New Delhi, Gr. 6

Inhaber H (1974) A set of suggested air quality indices for Canada. Atmos Environ 9(3):353-364

Jonnalagadda SB, Mhere G (2001) Water quality of the Odzi River in the eastern highlands of Zimbabwe. Water Res 35(10):2371-2376

Kannel PR, Lee S, Lee YS, Kanel SR, Khan SP (2007) Application of water quality indices and dissolved oxygen as indicators for river water classification and urban impact assessment. Environ Monit Assess 132:93-110

Khan AA, Paterson R, Khan H (2003) Modification and application of the CCME WQI for the communication of drinking water quality data in Newfoundland and Labrador. Presented at 38th, Central Symposium on Water Quality Research, Canadian Association on Water Quality 10-11 February 2003, Burlington, Canada

Kumar D, Alappat BJ (2004) Selection of the appropriate aggregation function for calculating leachate pollution index. Pract Period Hazard Toxic Radioact Waste Manage 8(4):253-264

Landwehr JM (1979) A statistic view of a class of water quality indices. Water Resour Res 15(2):460-468

Landwehr JM, Deininger RA (1976) A comparison of several water quality indexes. J Water Poll Control Fed 48(5):954-958

McDuffie B, Haney JT (1973) A proposed river pollution index. Spring 1973 Meeting of the American Chemical Society, Division of Water, Air and Waste Chemistry

Milovanovic M (2007) Water quality assessment and determination of pollution sources along the Axios/Vardar River, South-eastern Europe. Desalination 213:159-173

Nagels JW, Davies-Colley RJ, Smith DG (2002) A water quality index for contact recreation in New Zealand. Water Sci Technol 43(5):285-292

Ott WR (1978) Environmental indices: theory and practice. Ann Arbor Science Publishers, USA

Pesce SF, Wunderlin DA (2000) Use of water quality indices to verify the impact of Córdoba city (Argentina) on Suquia river. Water Res 34(11):2915-2926

Prasad B, Bose JM (2001) Evaluation of the heavy metal pollution index for surface and spring water near a lime stone mining area of the lower Himalayas. Environ Geol 41:183-188

Prati L, Pavanello R, Pesarin F (1971) Assessment of surface water quality by a single index of pollution. Water Res 5:741-751

Ross SL (1977) An index system for classifying river water quality. Water Pollut Control 76(1):113-122

Saaty TL (1980) The analytic hierarchy process. Mcgraw Hill International Publication, UK

Said A, Stevens D, Sehlke G (2004) An innovative index for evaluating water quality in streams. J Environ Manage 34(3):406-414

Smith DG (1989) A new form of water quality index for rivers and streams. Water Sci Technol 21(2):123-127

Smith DG (1990) A better water quality indexing system for rivers and streams. Water Res 24(10):1237-1244

Stoner JD (1978) Water quality indices for specific water uses. USGS Circular770, Reston, Va

Swamee PK, Tyagi A (2000) Describing water quality with aggregate index. J Environ Eng-ASCE 126(5):451-455

Swamee PK, Tyagi A (2007) Improved method for aggregation of water quality subindices. J Environ Eng-ASCE 133(2):220-225

Truett JB, Johnson AC, Rowe WD, Feigner KD, Manning LJ (1975) Development of water quality management indices. Water Resour Bull 11(3):436-448

Walski TM, Parker FL (1974) Consumers water quality index. J Environ Eng-ASCE 100(3):593-611 